American Journal of Environmental Sciences 5 (5): 669-677, 2009

ISSN 1553-345X

(C) 2009 Science Publications

\title{
Detecting Hornbeam Trees Phenological Characteristics of Mountain Forest
}

\author{
${ }^{1}$ Sasan Babaei Kafaki, ${ }^{1}$ Asadollah Mataji and ${ }^{2}$ Seyed Armin Hashemi \\ ${ }^{1}$ Department of Forestry, Faculty of Agriculture and Natural Resources, \\ Islamic Azad University, Science and Research Branch, Tehran, Iran \\ ${ }^{2}$ Department of Forestry, Islamic Azad University, \\ Science and Research Branch, Tehran, Iran
}

\begin{abstract}
Problem statement: Phenology is the study of the seasonal occurrence of developmental or life cycle events, such as bud break, flowering, or autumn leaf drop. The proposed study attempted to quantify changes in Carpinus betulus L. phenology of deciduous broad leaf forest between the years 2003-2006. Approach: Phenological studies were fulfilled during four years as from January 2003December 2006 by using ground observations and IRS1C/1D -LISS-III data. This study was performed on different altitudes and different aspects. The six sample plots were selected in study area. The statistical analysis showed that there were significant differences between the phonological characteristics in respect to the different site physiographical characteristics. Results: Leaf appearance at this type begins at the first of the third week of April Mostly and continues up to the first week of May. Leaves in this species begin to fall as from the beginning of the fourth week of November and will continue up to the end of first week of December. Furthermore there were significant negative correlation between average precipitation and average air temperature and there of the phonological characteristics. The correlation between average air temperature and leaf mature and fall date was significantly negative. The present study was specified that among the factors of study case, altitude from sea level had in priority and delay of appearance of phenological event has more obvious role out of the other factors. And also, the results show that over the study period, the growing season duration has lengthened by 1.8 days year $^{-1}$ in study region. The green-up of vegetation has advanced in the spring by 1.2 days year ${ }^{-1}$ and the dormancy delayed in autumn by 0.6 days year ${ }^{-1}$. The altitude from sea level had in priority and delay of appearance of phenological event has more obvious role out of the other factors. Conclusion: The growing season duration of Iran's deciduous broad leaf forest was significantly lengthened, primarily through an earlier green-up and a later dormancy during the period of 2003-2006.
\end{abstract}

Key words: Leaved period, Air temperature, NDVI, Leaf abscission, Anthesis

\section{INTRODUCTION}

Phenology is the study of the seasonal occurrence of developmental or life cycle events, such as bud break, flowering, or autumn leaf drop ${ }^{[22]}$. The timing of these events is known to be sensitive to short- and longterm variability in climate and is thus a robust indicator of the effects of climate change, especially observed rising temperatures ${ }^{[2,5,8,27,33,34]}$. In Britain, mean flowering dates of 385 plant species advanced by 4.5 days during the 1990s compared with the 1954-1990 mean and this is almost certainly linked to recent warming trends ${ }^{[8]}$. In the northeastern United States, changes in lilac, apple and grape phenology suggest that spring has advanced by $2-8$ days over the last three or four decades, consistent with patterns across North America as a whole $e^{[28,36]}$. Furthermore, there is also strong indirect evidence that the onset of spring has been occurring progressively earlier in recent decades ${ }^{[2,9,14]}$. A warming experiment with two Acer species indicates that warmer temperatures will likely lengthen the growing season, but earlier bud break and later senescence may expose plants to damaging frosts in the spring and incomplete resorption of foliar $\mathrm{N}$ in the autumn ${ }^{[20]}$. We focus on the phenology of bud break and leaf expansion to senescence (coloration and leaf drop). The timing of such events is important because leaves are the organs by which plants convert solar

Corresponding Author: Seyed Armin Hashemi, Ph.D student, Department of Forestry, Science and Research Branch, Islamic Azad University, Postal Code: 14515/4933, Tehran, Iran 
energy to chemical energy through the fixation of atmospheric carbon dioxide into carbohydrates ${ }^{[13]}$. Thus, it is to be expected that growing season length should be an important control on primary productivity ${ }^{[1,10,14,25]}$ phenology has emerged recently as an important focus for ecological research ${ }^{[16]}$. Assessment of vegetation phenology using remotely sensed data has a long history ${ }^{[24]}$ with more recent studies making use of satellite data to examine the potential effects of climate change on phenology ${ }^{[33]}$.

On the other hand, There have been recent attempts to link satellite derived signals (e.g., the Normalized Difference Vegetation Index (NDVI)) to phenology $y^{[7,27,33]}$. The timing and progression of plant development may provide information to help researchers make inferences about the conditions of plants and their environment such as soil moisture, soil temperature, illumination, temperature ${ }^{[23]}$. Changes in the phonological events may therefore signal important year-to-year climatic variations or even global environmental change ${ }^{[3]}$.
Satellite imagery has the advantage of spatial integration (cf. field measurements on a limited number of individuals), but its main problem is that the physiological significance of various remote sensing indices is not entirely clear. This study aims to quantify changes in Carpinus betulus L. phenology of deciduous broad leaf forest between the years 2003-2006.

\section{MATERIALS AND METHODS}

Study area: The research has performed in selected plots of Guilan Province, in the North of Iran (Fig. 1). The each selected plot area is one hectare. We selected 6 plots of hornbeam trees from $480-1170 \mathrm{~m}$ above sea level were determined in mountainous region (Table 1 and Fig. 1). Six sample plots in one hectare area, in square shape, has been selected that (Fig. 1c), indicates situation of sample plots. The plots have pure stand of hornbeam trees. The mean annual precipitation in deciduous broadleaf forests is $1139 \mathrm{~mm} \mathrm{year}^{-1}$.

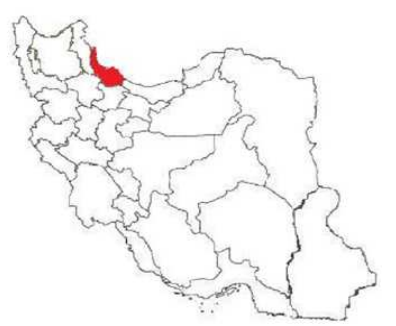

(a)

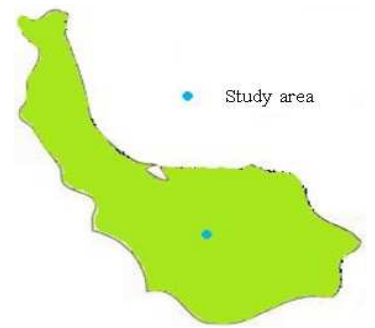

(b)

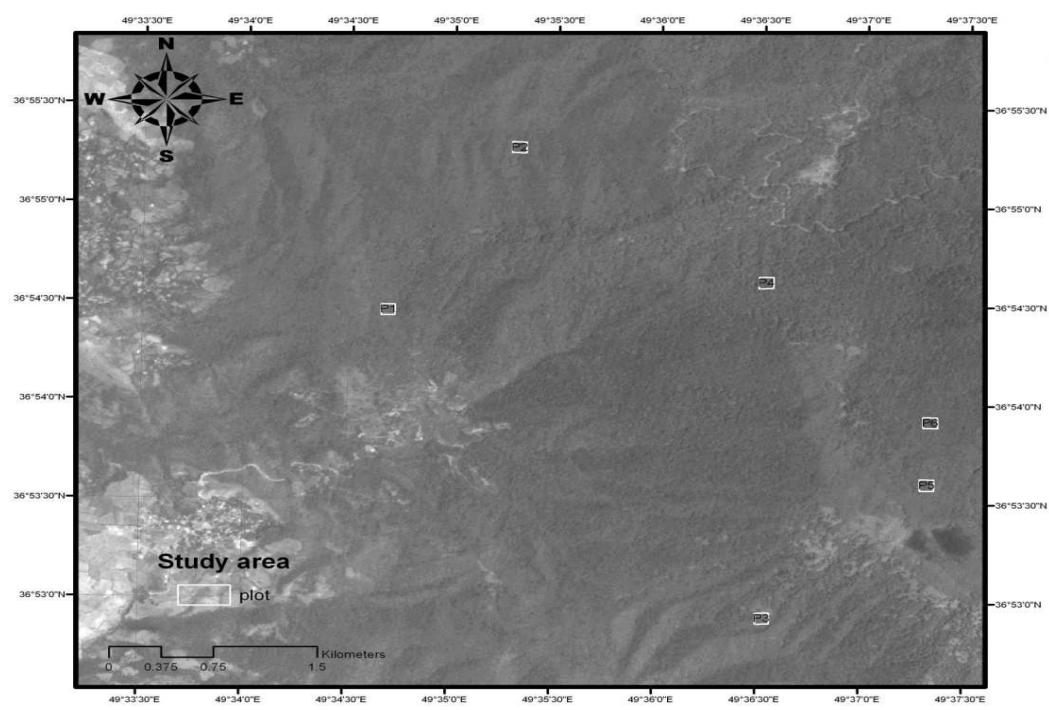

(c)

Fig. 1: Location of region in Iran (a), location of study area in region (b) distribution plots of hornbeam trees in study area (c) 
This region is covered by deciduous broadleaf forests, grasslands, shrubs, cultivation. The scope of the study was limited to one vegetation type as follows: Carpinus betulus L. of deciduous broad leaf forest (Fig. 1c). Phenology monitoring of hornbeam trees by using ground observations and IRS-LISS-III data in each plot.

Data: LISS-III data at a spatial resolution of $23.5 \times 23.5$ $\mathrm{m}^{2}$ and 24 day interval were acquired from Iran agency space from the IRS-LISSIII Land data set for the period January 2003 to December 2006.We used 60 IRSLISSIII images in this study. Monthly climate data used in this study include temperature and precipitation data, produced by handy type thermo-hygrometers (HOBO, H8 Pro Series and USA), for the years 2003-2006. We set handy type thermo-hygrometers at 6 selected plots. Using these data, we can calculate monthly change of air temperature at voluntary points in the study site from the difference of altitude and season.

Phenological studies were fulfilled during four years as from Janury 2003 to December 2006 about Carpinus betulus L. This study was fulfilled in forestial regions of Guilan in altitudes and different aspect, in such a way that totally in study area in three altitude limitations: 400-700, 700-1000 and 1000-1300 m higher than sea surface and in two northern and southern aspects of 6 sample plots were selected in one hectare and in each one of sample plots, 20 trees were selected. All plots are pure stand of hornbeam trees (Carpinus betulus L.).

In selection of sample plots and trees, it was tried that the following cases will be considered:

- Sample plots will be as possible as available readily and near to main roads

- Among sample plots, some trees will be selected that will be in different diameters, accurate and good forms and without any sign of dieses or pest

The trees were selected of dominant species in each plot. The number 20 trees were selected in an altitude limit of 480-1170 m above sea level (Table 1). All trees have been considered in sample plots numbered through specific signs and were installed on trees. These trees have been invested regularly through 7-10 days during months of Jan., Feb. Mar., Apr., May, Jun., Jul., Aug., Sep., Oct., Nov., Dec. and required information was completed and registered. Trees phenology study is performed by using visual description of growth and leaf expansion and anthesis processes to senescence (coloration and leaf drop).

At the end of each year, the collected information was classified and consequently, date of commencement and completion of appearance of each phenology event, was identified with division of the year, in such a way that at the end of duration of execution of the plan, domain of appearance of phonologic event was determined, separately. Besides, the required climate information such as monthly precipitation and minimum and maximum and average of monthly temperature, minimum and maximum of monthly humidity for each year was collected and finally average of the mentioned climate factors was determined for 4 years of execution of study (Table 2).

Data analysis: The data, on the basis of year, altitude from sea level, aspects, were classified and analyzed. At first, following of the main and changed data of the normal distribution were studied by kolmogorovsmirnov test and the best data distribution was selected for data analysis. In order to study on difference or notdifference of year, aspects and altitude from the sea surface on the basis of each one phenological characteristics (in the view point of all specifications of study case up to leaf appearance, anthesis, completion of leaf, fruit ripe, leaf abscission) with consideration to normal and homogenous being of data, variance of analysis (One Way-ANOVA) was used. After being meaningful of the phenological characteristics for multiple comparing of averages, Duncan Test was used.

Table 1: Altitude from sea levels and aspect for the selected plots

\begin{tabular}{lcc}
\hline Plot & ASL $(\mathrm{m})$ & Aspect \\
\hline 1 & 480 & South \\
2 & 470 & North \\
3 & 800 & South \\
4 & 800 & North \\
5 & 1160 & North \\
6 & 1170 & South \\
\hline
\end{tabular}

Table 2: Climate information of study area in years of execution of the study (2003-2006)

\begin{tabular}{|c|c|c|c|c|c|c|c|c|c|c|c|c|}
\hline Specifications & Jan. & Feb. & Mar. & Apr. & May & Jun. & Jul. & Aug. & Sep. & Oct. & Nov. & Dec. \\
\hline Average of maximum temperature $\left({ }^{\circ} \mathrm{C}\right)$ & 13.70 & 10.60 & 15.6 & 21.9 & 26.5 & 32.0 & 36.3 & 37.3 & 34.8 & 29.9 & 16.2 & 14.2 \\
\hline Average of minimum temperature $\left({ }^{\circ} \mathrm{C}\right)$ & -7.75 & -8.50 & -5.3 & -0.7 & 5.3 & 9.9 & 15.6 & 16.3 & 13.5 & 7.1 & -0.9 & -5.6 \\
\hline Average of temperature $\left({ }^{\circ} \mathrm{C}\right)$ & 2.40 & 1.05 & 5.1 & 10.6 & 14.7 & 21.1 & 20.5 & 27.6 & 23.4 & 18.6 & 10.4 & 4.2 \\
\hline Average precipitation $(\mathrm{mm})$ & 90.40 & 110.20 & 96.2 & 120.8 & 88.8 & 75.0 & 65.0 & 96.0 & 119.0 & 98.0 & 110.0 & 70.0 \\
\hline
\end{tabular}


In order to study on correlation of characteristics, Pearson correlation coefficient was used. And also, regression analysis of the relationship between the onset dates of green-up was done and the corresponding year for the study area was calculated. The regression analysis of the relationship between the onset dates of vegetation dormancy, lengths of the growing season were done and the corresponding years for the study area were calculated.

Determining the 4-year averaged seasonal NDVI curves: The NDVI has been shown as a key indicator for inferring the dynamics of vegetation structure and function $^{[18]}$. Thus, the ability of the NDVI to monitor intra-annual and inter-annual spatial variability of vegetation provides a basis for spatio-temporal phenological investigations ${ }^{[19,26]}$. Several studies used the remotely sensed NDVI to characterize phenological events $^{[11,12,29,30]}$.

We calculated the 4-year averaged seasonal NDVI curves (patterns) for the selected plots at 24 day intervals from the entire data set during 2003-2006.

The Normalized Difference Vegetation Index (NDVI) has calculated from Eq. 1:

$\mathrm{NDVI}=\frac{\mathrm{NIR}-\mathrm{R}}{\mathrm{NIR}+\mathrm{R}}$

In this equation $\mathrm{R}$ is Band 2 (red: $620-680 \mathrm{~nm}$ ) and NIR is Band 3 (near infrared: $770-860 \mathrm{~nm}$ ) of LISS-III data.

\section{RESULTS}

Table 3 is general description of the time of happening of phenological characteristics in total trees in different altitudes, aspect and years. As this table indicates, average of days up to leaf appearance, flowering, completion of leaf, fruit ripe, leaves abscission in Carpinus betulus L. Sre orderly, are equal to 118DOY, 118DOY, 127DOY, 318 DOY, 330 DOY With consideration to the Table 3 of the specification of leaf appearance, flowering with changes coefficients equal to $12.9 \%$ has the most diversity and specification of fruit ripe with $1.4 \%$ changes coefficient has had the least diversity. Results variances of analysis (One-Way ANOVA) of study area, among phenological characteristics, have been mentioned in Table 4. As this table indicates, among different levels of the study case, many of factors of study case in this plan consisting of year, altitude, aspect in the view point of all specifications of study case up to leaf appearance, antehsis, completion of leaf, fruit ripe, leaf abscission in significant level $1 \%$, significant difference was observed. This matter indicates very much diversity related to phenological specifications in different years (2003-2006), different altitudes (domains of 400-700, 700-1000 and 1000$1300 \mathrm{~m}$ ) and different aspects (northern and southern). This matter indicates that phenological specifications in the study case species, is under effect of climate and environmental factors. Table 5-7, orderly, indicate the comparison between specifications of the study area in years, altitudes and aspects of the study area. About years of study area (Table 5) is seen meaningful differences among appearance of vital events, too, in such a way that in the year (2005), because of being better of climate conditions, trees growth has began sooner than the other years, noticeable. And in the year 2003 this phenomena has happened later than the other years. In Table 6, also it is seen that through increase of altitude from the sea surface, appearance of some phonology events such as leaf and flower appearance, completion of leaf happens later and Leaf abscission happens sooner. Consequently, Table 7 indicates that only in two components of diameter and Leaf abscission, meaningful difference have been seen among the aspects of the study case, in such a way that average of trees diameters in southern aspect is more than northern aspect and fruit and leaf abscission have happened sooner in northern aspects.

Table 3: Description statistic of time of appearance of phonological events in Carpinus betulus L.

\begin{tabular}{lllllr}
\hline $\begin{array}{l}\text { Phonologic } \\
\text { events }\end{array}$ & $\begin{array}{l}\text { Minimum } \\
\text { (DOY) }\end{array}$ & $\begin{array}{l}\text { Maximum } \\
\text { (DOY) }\end{array}$ & $\begin{array}{l}\text { Domain } \\
\text { (days) }\end{array}$ & $\begin{array}{l}\text { Average } \\
\text { (DOY) }\end{array}$ & $\begin{array}{l}\text { CV } \\
(\%)\end{array}$ \\
\hline Leaf appearance & 101 & 131 & 31 & 118 & 12.9 \\
Anthesis & 101 & 131 & 31 & 118 & 12.9 \\
Leaf completion & 110 & 146 & 36 & 127 & 8.8 \\
Fruit ripe & 311 & 336 & 25 & 318 & 1.4 \\
Leaf abscission & 307 & 356 & 49 & 330 & 3.2 \\
\hline
\end{tabular}

Table 4: Analysis of variance of the specifications of study case Phonologic Leaf Completion Fruit Leaf \begin{tabular}{llll} 
events appearance Anthesis of leaf ripe abscission \\
\hline
\end{tabular} \begin{tabular}{llllll}
\hline Amount F & F & F & F & F & F
\end{tabular} $\begin{array}{llllll}\text { Year } & 8.1 * * & 8.1 * * & 6.02 * * & 65.52 * * & 26.04 * *\end{array}$

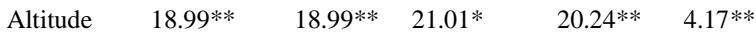

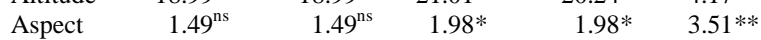
**: Significant at the 0.01 ; *: Significant at the 0.05 ; ns: Nosignificant

Table 5: Comparison between averages appearance of phenological events of the years in study area

\begin{tabular}{llllll}
\hline Year & $\begin{array}{l}\text { Leaf } \\
\text { appearance }\end{array}$ & Anthesis & $\begin{array}{l}\text { Completion } \\
\text { of leaf }\end{array}$ & $\begin{array}{l}\text { Fruit } \\
\text { ripe }\end{array}$ & $\begin{array}{l}\text { Leaf } \\
\text { abscission }\end{array}$ \\
\hline 2003 & $122 \mathrm{a}$ & $122 \mathrm{a}$ & $129 \mathrm{~b}$ & $319 \mathrm{a}$ & $336 \mathrm{a}$ \\
2004 & $120 \mathrm{~b}$ & $120 \mathrm{~b}$ & $129 \mathrm{~b}$ & $314 \mathrm{c}$ & $323 \mathrm{c}$ \\
2005 & $110 \mathrm{c}$ & $110 \mathrm{c}$ & $120 \mathrm{c}$ & $319 \mathrm{a}$ & $327 \mathrm{~b}$ \\
2006 & $119 \mathrm{~b}$ & $119 \mathrm{~b}$ & $131 \mathrm{a}$ & $317 \mathrm{~b}$ & $335 \mathrm{a}$
\end{tabular}

Averages with different letters have significant at the 0.01 
Am. J. Environ. Sci., 5 (5): 669-677, 2009

Table 6: Comparison between average of trees diameter and appearance of phenological events in the altitudes of study area

\begin{tabular}{lllllll}
\hline Altitude & DBH $(\mathrm{cm})$ & Leaf appearance & Anthesis & Completion of leaf & Fruit ripe & Leaf abscission \\
\hline $400-700$ & $28.2 \mathrm{a}$ & $112 \mathrm{c}$ & $112 \mathrm{c}$ & $121 \mathrm{c}$ & $318 \mathrm{a}$ & $335 \mathrm{a}$ \\
$700-1000$ & $25.4 \mathrm{~b}$ & $118 \mathrm{~b}$ & $118 \mathrm{~b}$ & $127 \mathrm{~b}$ & $319 \mathrm{a}$ & $240 \mathrm{~b}$ \\
$1000-1300$ & $20.8 \mathrm{c}$ & $119 \mathrm{a}$ & $119 \mathrm{a}$ & $130 \mathrm{a}$ & $317 \mathrm{~b}$ & $328 \mathrm{c}$ \\
\hline
\end{tabular}

Averages with different letters have significant at the 0.01

Table 7: Comparison between diameters of trees (DBH) and appearance of phenological event of the aspects in the study area

\begin{tabular}{lll}
\hline Aspect & DBH $(\mathrm{cm})$ & Leaf abscission \\
\hline North & $26.3 \mathrm{a}$ & $332 \mathrm{a}$ \\
South & $22.6 \mathrm{~b}$ & $329 \mathrm{~b}$ \\
\hline
\end{tabular}

Averages with different letters have significant at the 0.01

Table 8: Matrix of correlation of specifications of study area and collected climate factors during the period of execution

\begin{tabular}{|c|c|c|c|c|c|c|c|c|c|c|c|}
\hline $\bar{X}$ & $\mathrm{~A}$ & B & $\mathrm{C}$ & $\mathrm{D}$ & $E$ & $\mathrm{~K}$ & $\mathrm{~L}$ & M & $\mathrm{N}$ & $\mathrm{O}$ & $\mathrm{P}$ \\
\hline$\overline{\mathrm{A}}$ & $-0.125^{* *}$ & & & & & & & & & & \\
\hline B & $-0.129 * *$ & $0.999 * *$ & & & & & & & & & \\
\hline $\mathrm{C}$ & $-0.146 * *$ & $0.896^{* *}$ & $0.896^{* *}$ & & & & & & & & \\
\hline $\mathrm{D}$ & $-0.950 \mathrm{~ns}$ & $-0.072 \mathrm{~ns}$ & $-0.720 \mathrm{~ns}$ & $-0.65 n s$ & & & & & & & \\
\hline $\mathrm{E}$ & $0.005 \mathrm{~ns}$ & $0.086^{*}$ & $0.087^{*}$ & $0.060 \mathrm{~ns}$ & $0.289 * *$ & & & & & & \\
\hline $\mathrm{K}$ & $0.119 * *$ & $-0.271 * *$ & $-0.269 * *$ & $-0.034 * *$ & $0.442 * *$ & $0.066 \mathrm{~ns}$ & & & & & \\
\hline $\mathrm{L}$ & $-0.082 *$ & $0.285^{* *}$ & $0.288^{* *}$ & $0.399 * *$ & $0.507 * *$ & $0.306^{* *}$ & $0.367 * *$ & & & & \\
\hline M & $0.185^{* *}$ & $0.230^{* *}$ & $0.229^{* *}$ & $0.181^{* *}$ & $0.059 \mathrm{~ns}$ & $0.059 \mathrm{~ns}$ & $0.218 * *$ & $-0.193 * *$ & & & \\
\hline $\mathrm{N}$ & $-0.125 * *$ & $-0.145 * *$ & $-0.143 * *$ & $0.003 \mathrm{~ns}$ & $-0.025 \mathrm{~ns}$ & $-0.202 * *$ & $0.080 *$ & $0.177 * *$ & $-0.728 * *$ & & \\
\hline $\mathrm{O}$ & $0.181 * *$ & $-0.263 * *$ & $-0.263 * *$ & $-0.180 * *$ & $-0.077 \mathrm{~ns}$ & $0.218 * *$ & $0.471 * *$ & $-0.524 * *$ & $0.590 * *$ & $-0.118 * *$ & \\
\hline $\mathrm{P}$ & $0.390 \mathrm{~ns}$ & $-0.306^{* *}$ & $-0.305^{* *}$ & $-0.131 * *$ & $-0.072 \mathrm{~ns}$ & $-0.314 * *$ & $0.411 * *$ & $-0.254 * *$ & $-0.125^{* *}$ & $0.675^{* *}$ & $0.653 * *$ \\
\hline
\end{tabular}

**: Significant at the 0.01; *: Significant at the 0.05; ns: Non- significant; A: Leaf appearance; B: Anthesis (flowering); C: Completion of leaf; D: Fruit ripe; E: Leaf abscission; K: Mean precipitation; L: Average of maximum humidity; M: Average of minimum humidity; N: Average maximum temperature; O: Average minimum temperature; P: Average temperature

Table 8 indicates matrix of correlation of specifications among specifications of the study case and also climate factors such as precipitation, minimum and maximum and average of monthly temperature. As it can be seen in Table 8, amount of precipitation and average of temperature degree has negative and meaningful correlation with appearance of leaf, flower. It means through increase of the amount of precipitation and average of temperature degree, appearance of leaf and flower begin sooner. Correlation among the amount of the precipitation through fruit ripe is meaningful, too but was positive, means if amount of precipitation will be more, fruit ripe will fulfill later and through delay. Correlation among the amount of precipitation with leaf abscission, time up to completion of leaf was not meaningful, too. Correlation among the average of temperature degree with the time up to completion of leaf, Leaf abscission, is negative and meaningful. Consequently, through increase of temperature degree up to completion of leaf, Leaf abscission begins sooner. Figure 2 shows the seasonal variations in the 4 year averaged NDVI and temperature at the interval of 24 days for the entire plots. The early May was recognized as the mean onset period of greenup while late November as the mean onset period of vegetation dormancy for the plots. In contrast, the mean onset dates of dormancy occur in late November.

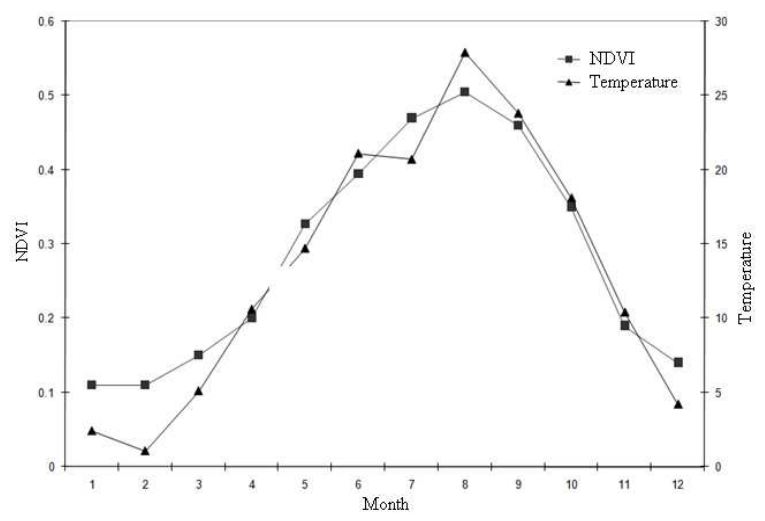

Fig. 2: Seasonal curves in the 4 year averaged 24 day NDVI and temperature

The highest NDVI thresholds for the onset dates of green-up (0.312) and dormancy (0.331) occur in broad leaf forests. The onset date of green-up over study area has significantly advanced over the past 4 years $\left(\mathrm{R}^{2}=\right.$ $0.8, \mathrm{P}=0.01$ ), with an annual advance of 1.2 days year $^{-1}$ (Fig. 3a). The onset date of vegetation dormancy was delayed from 2003-2006 $\left(\mathrm{R}^{2}=0.18, \mathrm{P}=0.01\right)$, with an annual delay of 0.6 days year $^{-1}$ (Fig. 3b). The length of the growing season has increased by 1.8 days year ${ }^{-1}$ from 2003-2006 $\left(R^{2}=0.49, P=0.01\right)$ (Fig. 3c). Hornbeam trees of deciduous broad leaf forest exhibit advanced green-up and dormancy (Fig. 3). 


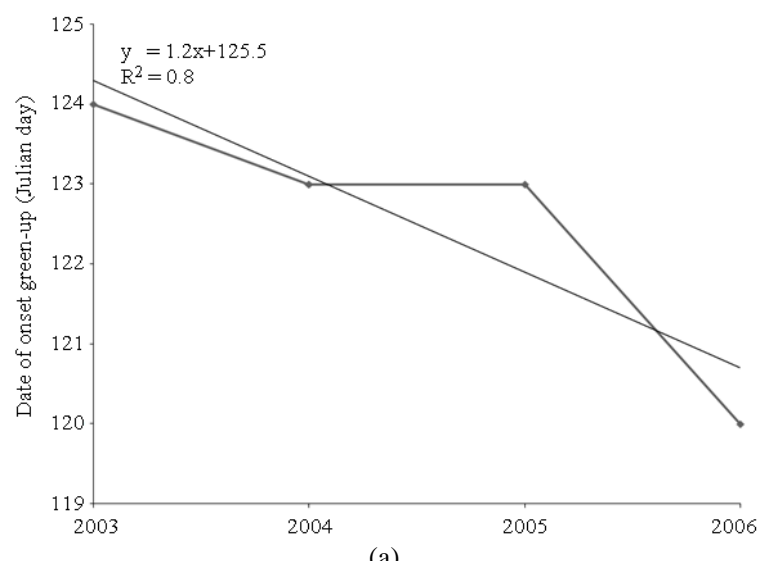

(a)

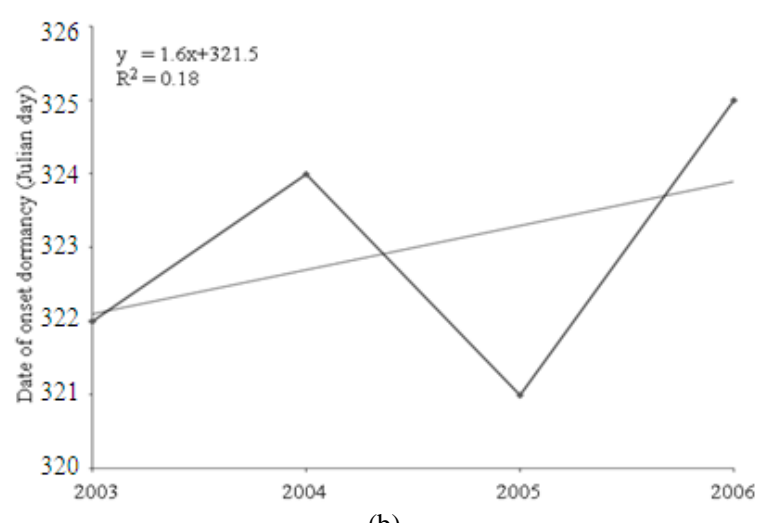

(b)

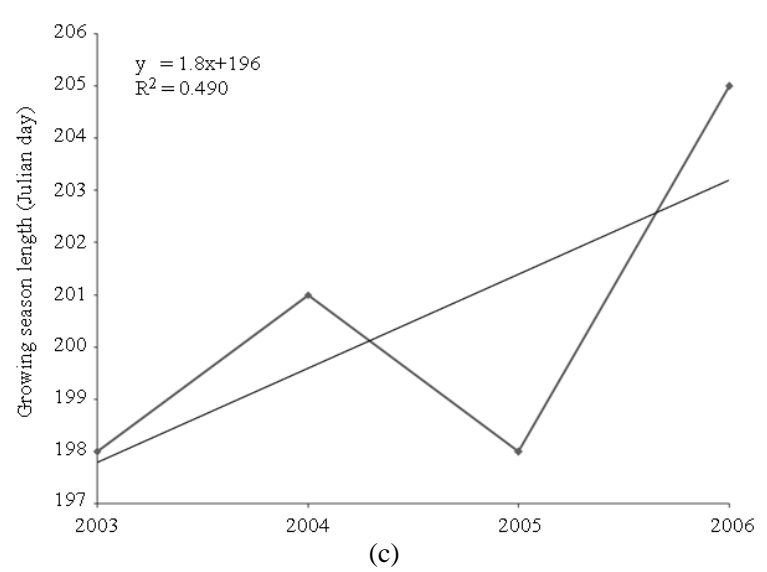

Fig. 3: Interannual variation in the onset dates of (a) green-up, (b) dormancy and (c) growing season length from 2003-2006

\section{DISCUSSION}

Appearance of phenological different steps in trees depend on different facts that among them, roll of regional and edaphically so effective in such a way that commencement of growth of trees is under direct effect of two factors of air temperature and precipitation. On the other hand, with consideration to this point that the altitude from sea level is under effect of regional facts, this matter has main role on appearance of phenological events. This matter in the present research and also the other researches that has been fulfilled in field aspect and in different elevations, have been confirmed ${ }^{[6]}$, in such a way that in the present study was specified that among the factors of study case, altitude from sea level had in priority and delay of appearance of phenological event has more obvious role out of the other factors, means that some phenomena such as germinating, flowering and completion of leaf have fulfilled with delay through increase of altitude from sea surface and vice versa some factors such as fruit ripe and specially Leaf abscission have been fulfilled through increase of altitude from sea level, sooner. Time of appearance of phenology events in Carpinus betulus L. Species depending on some factors such as situation of location and weather conditions has about one to two weeks delay. In this research, commencement of trees growth and leaf opening in the year 2005 has commenced with time difference equal to 9 to 12 days sooner than the other years of the study case that reason of this matter is higher temperature in April of this year in comparison with the other years. Flowering in trees of the study case, totally in spring season and majority will continue as from mid- April up to mid- May. Generally, with consideration to the gained results interpretation of appearance of the phenological event in trees of the study are as follows:

Germination (Leaf appearance): Leaf appearance at this type begins at the first of the third week of April Mostly and continues up to the first week of May. As Table 5-7 indicate that effect of aspect (northern and southern) in this time difference has not been meaningful and major changes have been observed in year and altitude domains. Leaf appearance is fulfilled through increase of altitude from sea surface through delay, too.

Flowering: Appearance of flowers has usually been begun in this species at the same time of Leaf appearance and from its beside, in such as a way that it continues as from the first of the third week of April and will continue up to first week of May. About flowering, the aspects of the study case have not indicated any meaningful difference with each other, too and major changes of the changes are seen in year and altitude of the study case. Through increase of altitude from sea surface, flowering occurs after delay. 
Leaf completion: Leaves in this species complete usually 15-20 days after germination, if the environmental conditions will be suitable and delay in beginning of cold season of Spring, in such a way that during this period, in different altitude domains, it begins as from the middle of the first week of May and will continue up to the end of the third week of May.

Fruit ripe: Fruits in this species mostly become ripe about 70 days after appearance meaning as from the first of the second week of November up to the end of the third week. About the time of beginning of these phenomena, aspects have not shown meaningful differences, but through increase of altitude from sea surface, the fruit will become ripe, sooner.

Leaf abscission: Leaves in this species begin to fall as from the beginning of the fourth week of November and will continue up to the end of first week of December and sometimes up to the end of the first half of the December, too. Leaf abscission begins in higher altitude sooner and through increase of altitude, this matter will fulfill in delay. In some trees of this specie, leaves have become dried and yellow, completely, but in Autumn, falling does not occur and remain on the branch even up to Spring of the next of the next year in dried aspect, sometimes. Also, Leaf abscission has begun sooner than southern direction and in the year 2004 because of being less of temperature degree than the other years. This study estimated that the onset date of the green up of the selected plots advanced on average by 1.2 days year ${ }^{-1}$ from 2003-2006. Some evidence also indicates a later onset of autumnal phenological events ${ }^{[4,32]}$. This study estimated that the onset date of vegetation dormancy of the selected zone of Iran was delayed with an annual delay of 0.6 days year $^{-1}$ from 2003-2006. Increasing in growing season length could increase the mean forest net primary production ${ }^{[35]}$. The length of the growing season duration mainly impacts the interannual variability of plant growth and thereby, also strongly affects the net carbon dioxide uptake ${ }^{[21]}$. This study estimated that the mean onset date of length of the growing season over study area has significantly advanced with an annual advance of 1.8 days year ${ }^{-1}$. The global warming induced by increasing atmospheric greenhouse gases, has been suggested to be the major cause of the advance and extension of the growing season ${ }^{[17,31,37]}$. The Normalized Difference Vegetation Index (NDVI), which is derived from infrared channel and nearinfrared channel remote sensing data, is a good indicator of photosynthesis (vegetation activity). Disease, competition, soil factors and weather conditions can profoundly influence plant phonological statu ${ }^{[15]}$. The global warming has been suggested to be the major cause of the advance and extension of the growing season ${ }^{[17,31,37]}$. Evidence from remote sensing data $^{[31,37]}$ all revealed that the spring advanced and growing season duration significantly lengthened over the past two decades at the middle and high latitudes in the northern hemisphere.

\section{CONCLUSION}

The growing season duration of Iran's deciduous broad leaf forest was significantly lengthened, primarily through an earlier green-up and a later dormancy during the period of 2003-2006. This strongly supports the lengthening of the growing season duration owing to the global warming at the northern high latitudes in the recent decades. Nonetheless, further investigative work remains to be carried out, especially in phenological Characteristics and remote sensing applications.

\section{REFERENCES}

1. Aber, J.D., S.V. Ollinger and C.A. Federer, 1995. Predicting the effects of climate change on water yield and forest production in the northeastern United States. Climate Res., 5: 207-222. http://www.int-res.com/abstracts/cr/v05/n3/p207-222/

2. Badeck, F.W., A. Bondeau and K. Bottcher, 2004. Responses of spring phenology to climate change. New Phytol., 162: 295-309. DOI: 10.1016/S01681923(01)00233-7

3. Botta, A., N. Viovy, P. Ciais, P. Friedlingstein and Pand Monfray, 2000. A global prognostic scheme of leaf onset using satellite data. Global Change Biol., $6:$ 709-725. http://www.ingentaconnect.com/content/bsc/gcb/20 00/00000006/00000007/art00001

4. Chmielewski, F.M. and T. Rotzer, 2001. Response of tree phenology to climate change across Europe. Agric. For. Meteorol., 108: 101-112. http://www.ingentaconnect.com/content/els/01681 923/2001/00000108/00000002/art00233

5. Chuine, I., P.Yiou and N. Viovy, 2004.Grape ripening as a past climate indicator. Nature., 432: 289-290. DOI: $10.1038 / 432289$ a

6. Ferraz, D.K., R. Artes, W. Mantovani and L.M. Magalhaes, 1998. Phenology of tree species in a urban forest fragment in southeastern Brazil. Brazilian Journal of Biol., 59: 305-317. http://www.scielo.br/scielo.php?script=sci_abstract \&pid=S0034$71081999000200013 \& \operatorname{lng}=$ en\&nrm=iso\&tlng=en 
7. Fisher, J.I., J.F. Mustard and M.A. Vadeboncoeur, 2006. Green leaf phenology at Landsat resolution: Scaling from the field to the satellite. Remote Sens. Environ., $\quad 100$ : 265-279. $\quad$ DOI: 10.1016/J.RSE.2005.10.022

8. Fitter, A.H. and R.S.R. Fitter, 2002. Rapid changes in flowering time in British plants. Science, 296: 1689-1691. DOI: 10.1126/science.1071617

9. Fitzjarrald, D.R., O.C. Acevedo and K.E. Moore, 2001.Climatic consequences of leaf presence in the eastern United States. J. Climate, 14: 598-614. DOI: $\quad 10.1175 / 1520-0442(2001) 014<0598$ : CCOLPI $>2.0 . \mathrm{CO} ; 2$

10. Goulden, M.L., J.W. Munger and S.M. Fan, 1996. Exchange of carbon dioxide by a deciduous forest: response to interannual climate variability. Science, 271: 1576-1578.

http://www.sciencemag.org/cgi/content/abstract/27 $1 / 5255 / 1576$

11. Goward, S.N. and D.G. Dye, 1987. Evaluating North American net primary productivity with satellite observations. Adv. Space Res., 7: 165-174. DOI: 10.1016/0273-1177(87)90308-5

12. Justice, C.O., B.N. Holben and M.O. Gwynne, 1986. Monitoring East African vegetation using AVHRR data. Int. J. Remote Sens., 7: 1453-1474. DOI: $10.1080 / 01431168608948948$

13. Lechowicz, M.J., 1984. Why do temperate deciduous trees leaf out at different times? Adaptation and ecology of forest communities. Am. Natural., 124: 821-842. DOI: 10.1086/284319

14. Keeling, C.D., JFS. Chin and TP. Whorf, 1996. Increased activity of northern vegetation inferred from atmospheric $\mathrm{CO} 2$ measurements. Nature, 382: 146-149. DOI: $10.1038 / 382146 a 0$

15 Menzel, A., 2000.Trends in phenological phases in Europebetween1951 and1996.In.J. Biometeorol.,44: 76-81 .DOI:10.1007/s004840000054

16. Menzel, A., N. Estrella and P. Fabian, 2001. Spatial and temporal variability of the phenological seasons in Germany from1951 to 1996. Global Change Biol., 7: 657-666. http://www3.interscience.wiley.com/journal/12084 6179/abstract?CRETRY $=1 \&$ SRETRY $=0$

17. Menzel, A. and P. Fabian, 1999. Growing season extended in Europe. Nature, 397: 659-659. DOI: $10.1038 / 17709$

18. Nemani, R., C.D. Keeling, H. Hashimoto, W.M. Jolly, S.C. Piper and C.J. Tucker, 2003. Climate drivenincreases in global terrestrial net primary production from 1982-1999. Science, 300: 1562-1563. DOI: $10.1126 /$ science. 1082750
19. Nightingale, J.M. and S.R. Phinn, 2003. Assessment of relationships between precipitation and satellite derived by vegetation condition within South Australia. Aust. Geogr. Stud., 41: 180-195. http://www3.interscience.wiley.com/journal/11886 4470/abstract

20. Norby, R.J., J.S. Hartz-Rubin and M.J. Verbrugge, 2003. Phenological responses in maple to experimental atmospheric warming and $\mathrm{CO}_{2}$ enrichment. Global Change Biol., 9: 1792-1801. DOI: 10.1111/j.1365-2486.2003.00714.x

21. Randerson, J.T., C.B. Field and I.Y. Fung, 1999. Increases in early season ecosystem uptake explain recent changes in the seasonal cycle of atmospheric $\mathrm{CO}_{2}$ at high northern latitudes. Geophys. Res. Lett., 26: 2765-2768.

http://www.agu.org/pubs/crossref/1999/1999GL90 0500.shtml

22. Rathcke, B. and E.P. Lacey, 1985.Phenological patterns of terrestrial plants. Annu. Rev. Ecol. Systemat., 16 : $179-214 . \quad$ DOI: 10.1146/annurev.es.16.110185.001143

23. Reed, B.C., J.F. Brown and D. Vanderzee, 1994. Measuring phenological variability from satellite imagery. J. Vegetat. Sci., 5: 703-714. DOI: $10.2307 / 3235884$

24. Rea, J. and M. Ashley, 1976. Phenological evaluations using Landsat-1 sensors.International J. Biometeorol., $\quad 20$ : 240-248. $\quad$ DOI: 10.1007/BF01553667

25. Running, S.W. and R.R. Nemani, 1991. Regional hydrologic and carbon balance responses of forests resulting from potential climate change. Climat. Change, 19: 349-368. DOI: 10.1007/BF00151173

26. Schwartz, M.D. and B.C. Reed, 1999. Surface phenology and satellite sensor-derived onset of greenness: An initial comparison. Int. J. Remote Sens., 20 : 3451-3457. DOI: 10.1080/014311699211499

27. Schwartz, M.D., B.C. Reed and M.A. White, 2002. Assessing satellite derived start-of-season measures in the coterminous USA. Int. J. Climatol., 22: 1793-1805. DOI: 10.1002/joc.819

28. Schwartz, M.D. and B.E. Reiter, 2000. Changes in North American spring. Int. J. Climatol., 20: 929-932. DOI: $10.1002 / 1097-$ 0088(20000630)20:8<929::AIDJOC557>3.0.CO;2-5

29. Tateishi, R. and M. Ebata, 2004. Analysis of phenological change patterns using 1982-2000 Advanced Very High Resolution Radiometer (AVHRR) data. Int. J. Remote Sens., 25: 2287-2300. DOI: $10.1080 / 01431160310001618455$ 
30. Townshend, J.R.G. and C.O. Justice, 1986. Analysis of the dynamics of African vegetation using the normalized difference vegetation index. Int. J. Remote Sens., 7: 1435-1445. DOI: 10.1080/01431168608948946

31. Tucker, C.J., D.A. Slayback and J.E. Pinzon, 2001. Higher northern latitude normalized difference vegetation index and growing season trends from 1982-1999. Int. J. Biometeorol., 45: 184-190. DOI: 10.1007/s00484-001-0109-8

32. Walther, G.R., E. Post and P. Convey, 2002. Ecological responses to recent climate change. Nature, 416: 389-395. DOI: 10.1038/416389a

33. White, M.A., P.E. Thornton and S.W. Running, 1997. A continental phenology model for monitoring vegetation responses to interannual climatic variability. Global Biogeochem. Cycles, 11:217-234.

http://www.agu.org/pubs/crossref/1997/97GB0033 0. shtml

34. White, M.A. and R.R. Nemani, 2003. Canopy duration has little influence on annual carbon storage in the deciduous broad leaf forest. Global Change Biol., 9: 967-972. DOI: 10.1046/j.13652486.2003.00585.x
35. White, M.A., S.W. Running and P.E. Thornton, 1999. The impact of growing-season length variability on carbon assimilation and evapotranspiration over 88 years in the eastern US deciduous forest. Int. J. Biometeorol., 42: 139-145. DOI: $10.1007 / \mathrm{s} 004840050097$

36. Wolfe, D.W., M.D. Schwartz and A.N. Lakso, 2005. Climate change and shifts in spring phenology of three horticultural woody perennials in northeastern USA. Int. J. Biometeorol., 49: 303-309. DOI: $10.1007 / \mathrm{s} 00484-004-0248-9$

37. Zhou, L.M., C.J. Tucker and R.K. Kaufmann, 2001. Variations in northern vegetation activity inferred from satellite data of vegetation index during 1981-1999. J. Geophys. Res. Atmosph., 106: 20069-20083. http://www.agu.org/pubs/crossref/2001/2000JD000 115.shtml 